\title{
The importance of extragenital endometriosis for surgeons
}

\section{Cerrahlar için ekstragenital endometriozisin önemi}

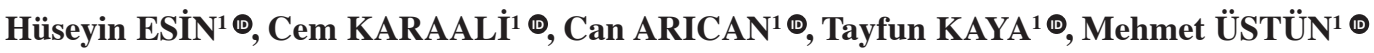 \\ Gülden DİNiZ ${ }^{2 \oplus}$, Cengiz AYDIN ${ }^{1 \oplus,}$ Mustafa EMIROĞLU ${ }^{1 \oplus}$

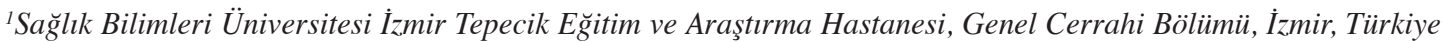 \\ ${ }^{2}$ Sağlık Bilimleri Üniversitesi İzmir Tepecik Ĕ̆itim ve Araştırma Hastanesi, Patoloji Bölümü, İzmir, Türkiye
}

\begin{abstract}
Objective: In this study, the characteristics of patients who were treated in our General Surgery Clinic with extragenital endometriosis are described. In addition, increasing the awareness of clinicians to these rare situations.is aimed.

Methods: Patients who were operated in General Surgery Clinic between January 2010 and January 2017 were included in the study. The data of the patients were retrospectively analyzed from their files. Demographic data, anamnesis and physical examination findings, localizations, and number of endometriomas with endometriosis were recorded.

Results: Sixteen patients who met the study criteria were included in the study. The mean age of the patients was $32.8 \pm 6.9$ (min-max: $21-44)$ years and $14(87.5 \%)$ patients were premenopausal women while all cases had undergone at least one or more than one cesarean sections The most frequent symptom was palpable mass $(n=15)$ and followed by cyclic pain $(n=12)$. Extragenital endometriomas were located close to the cesarean section scar in $13(81.25 \%)$, on umbilical region in two and inguinal region in one patient. The mean diameter of the masses was $39.5 \pm 18.1 \mathrm{~mm}$ (min-max: 10-75 $\mathrm{mm})$. The mean follow-up period of the patients was 43 months (range: 18-79 months). During the follow-up period, recurrence was detected in one patient.

Conclusion: Extrapelvic endometrioma should be suspected in the differential diagnosis in patients who had undergone gynecologic or obstetric surgery and had a mass lesion developed on the abdominal wall regardless of the presence of cyclic pain.
\end{abstract}

Keywords: Surgeon, extragenital endometriosis, cesarean section

\section{$\ddot{0 Z Z}$}

Amaç: Bu çalışmada, ekstragenital endometriozis nedeni ile Genel Cerrahi kliniğimizde opere edilmiş hastaların özellikleri tanımlanmaktadır. Ek olarak klinisyenlerin bu nadir durumlar karşısında farkındalığının artırılması amaçlanmıştır.

Yöntem: Ocak 2010 ile Ocak 2017 yılları arasında Genel Cerrahi Kliniğinde opere edilmiş hastalar çalışmaya alınmıştır. Hastaların verileri dosyalarından geriye dönük olarak incelenmiştir. Hastaların demografik verileri, öykü ve fizik bakı bulguları, endometriozis yerleşimleri ve sayıları kayıt edilmiştir.

Bulgular: Çalışma kriterlerine uygun olan 16 hasta çalışmaya alındı. Hastaların ortalama yaşı $32,8 \pm 6,9(21-44)$ idi. On dört $(\% 87,5)$ hastanın premenopozal dönemde olduğu, tüm olgulara en az bir ya da daha fazla sezaryen uygulandığı saptanmıştır. En sık saptanan semptom ele gelen kitle $(n=15)$ iken, ikinci sıklıkla siklik ağrı $(n=12)$ olduğu bulundu. Ekstragenital endometrioma $13(\% 81,25)$ hastada sezaryen skarına yakın yerleşimli iken, iki hastada umblikal, bir hastada ise inguinal bölge yerleşimli idi. Kitlelerin ortalama çapı 39,5 $\pm 18,1 \mathrm{~mm}(10-75 \mathrm{~mm})$ idi. Ortalama izlem süresi 43 ay (18-79 ay) idi. İzlem süresince bir hastada rekürrens saptandı.

Sonuç: Jinekolojik veya obstetrik bir ameliyat geçirmiş bir hastada karın duvarında gelişen kitlelerde siklik ağrı olsun ya da olmasın ayırıcı tanıda ekstragenital endometriomadan şüphelenilmelidir.

Anahtar kelimeler: Cerrah, ekstragenital endometriozis, sezaryen
Alındığı tarih: 28.08 .2018

Kabul tarihi: 09.10.2018

Yazışma adresi: Uzm. Dr. Hüseyin Esin, Güney Mah. 1140/1. Sk. No:1, 35180 - Yenişehir - Konak - 35180 - İzmir - Türkiye

e-mail: dr.hesin@hotmail.com

\section{Yazarlarm ORCID bilgileri:}

H.E. 0000-0001-9004-1794

C.K. 0000-0003-2743-7360

C.A. $0000-0002-0633-6171$

T.K. 0000-0001-7101-1952

M.Ü. 0000-0003-2646-5239

G.D. 0000-0003-1512-7584

C.A. $0000-0003-4713-2871$

M.E. 0000-0002-4968-2570 


\section{INTRODUCTION}

Endometriosis can be described as a condition in which the endometrial glands and stroma develop outside the uterine cavity. Ectopic endometrial tissues are primarily found in the pelvis, especially in the ovaries, and cause dysmenorrhea, pelvic pain and infertility. Endometriosis affects $6 \%-10 \%$ of women in their reproductive age ${ }^{(1)}$. Extragenital or extrapelvic endometriosis is located outside the genital tract and is detected in $8.9 \%$ of endometriosis cases ${ }^{(2)}$. Extragenital endometriosis (EE) can be detected in scar tissue in several different areas such as eyes, lungs, umbilicus, bile ducts, liver, skin and abdominal wall ${ }^{(3)}$. Endometriosis occurring in these different locations cause quite diverse symptoms, thus making the clinical diagnosis often difficult ${ }^{(4)}$. The palpable mass of EE can be with or without associated pain.

These masses cause problems in making a differential diagnosis as they could be mistaken for abscess, lipoma, lymphadenopathy, suture granuloma, foreign body or benign or malignant tumours ${ }^{(2,5)}$. This study describes the characteristics of patients who were treated in our general surgery clinic for EE. In addition, we intend to raise the awareness of surgeons in these rare situations.

\section{MATERIALS and METHODS}

This study was conducted using data collected between January 2010 and January 2017 from patients who were admitted to the general surgery clinic of the Tepecik Training and Research Hospital of University ofHealth Sciences The data of the patients with a pathological diagnosis of endometriosis were examined retrospectively using digital (ProBel Inc.) files.

Informed consent forms were obtained from all patients for these examinations and surgical procedures. Local ethics committee approval was obtained for this study, and demographic data, anamnesis and physical examination findings and localisations, and numbers of endometriomas were recorded. Patients whose recorded data were insufficient, who did not follow up with the required medical examinations and who had no extragenital disease despite their definitive pathological result indicating endometriosis were excluded from the study. The study patients were invited to regular medical examinations in the hospital. The median follow-up period of the patients was 43 months (range: 18-79 months), and investigations were carried out based on anamnesis, physical examination and ultrasonography.

\section{RESULTS}

EE was diagnosed incidentally when a patient was examined for ovarian cysts. None of the patients other than those with EE were examined by additional imaging methods, except ultrasound. EE was diagnosed correctly in 11 patients, whereas: granulomas in 2, hernia in 1 , abscess in 1 and tumour in 1 patient were histopathologically diagnosed during postoperative period.

Data of 16 out of 19 patients who were operated for endometriosis in the general surgery clinic, were analysed in this study. Two patients with missing data and one patient who could not attend the follow-up check-ups were excluded. The mean age of the patients was $32.8 \pm 6.9$ years (range: $21-44$ years). Of the 16 study patients, $14(87.5 \%)$ were premenopausal, and all patients had at least one or more caesarean sections. The most frequent symptom was found to be the palpable mass $(n=15)$, followed by cyclic pain $(n=12)$.

EEs were located near the caesarean section scar in 13, umbilical region in 2 and inguinal region in 1 patient. EE located on the abdominal wall was close to the caesarean section scar tissue in 11 of our patients, and mass lesions of these patients were located in the rectus muscle.

The mass lesions of all patients were resected leaving a clear surgical margin. The mean diameter of the masses was $39.5 \pm 18.1 \mathrm{~mm}$ (range: $10-75 \mathrm{~mm}$ ). During the follow-up period, endometriosis recurred in one patient, and was treated by excision. The details of the patients are summarised in Table 1. 
Table 1. Characteristics of patients with extragenital endometriosis.

\begin{tabular}{|c|c|c|c|c|}
\hline & $\mathbf{n}$ & $\%$ & Range & Mean \pm SD \\
\hline Age & & & $21-44$ & $32.8 \pm 6.9$ \\
\hline Parity & & & $1-4$ & 2 \\
\hline Premenopausal & $14 / 16$ & 87.5 & & \\
\hline Caesarean Section & & & $16 / 16$ & 100 \\
\hline \multicolumn{5}{|l|}{ Presenting symptom } \\
\hline Mass & 15 & 93.75 & & \\
\hline Pain (cyclic) & 12 & 75 & & \\
\hline Pain (noncyclic) & 3 & 18.75 & & \\
\hline Dyspareunia & 0 & 0 & & \\
\hline Dysmenorrhea & 1 & 6.25 & & \\
\hline Bleeding & 0 & 0 & & \\
\hline Duration of symptoms (months) & & & $1-41$ & $12.54 \pm 11.72$ \\
\hline \multicolumn{5}{|l|}{ Diagnosing tool } \\
\hline Ultrasonography & 15 & 98.75 & & \\
\hline CT & 0 & 0 & & \\
\hline MRI & 1 & 6.25 & & \\
\hline Single mass & 16 & 100 & & \\
\hline Two masses & 0 & 0 & & \\
\hline Accurate diagnosis & 11 & 68.75 & & \\
\hline Wrong diagnosis & 5 & 31.25 & & \\
\hline \multicolumn{5}{|l|}{ Location of the mass } \\
\hline Near the scar & 13 & 81.25 & & \\
\hline Far from the scar & 3 & 18.75 & & \\
\hline Diameter of the mass (mm) & & & $10-75$ & $39.5 \pm 18.1$ \\
\hline Recurrence & 1 & 6.2 & & \\
\hline Follow-up (months) & & & $18-79$ & $43.1 \pm 17.6$ \\
\hline
\end{tabular}

CT, computarized tomography; MRI, magnetic resonance imaging; mo, months.

\section{DISCUSSION}

This study shows that EE most commonly develops near the caesarean section scar. Abdominal wall endometriosis is found in $0.03 \%-1.5 \%$ of the patients during postoperative period after cesarean section ${ }^{(6)}$. Endometrial implants can generally be found on the surface near the scar tissue or in the muscles of the same region ${ }^{(7)}$. The primary relationship between the scar tissue and the developed endometrioma in such areas can be explained by the theory that is based on the spread of endometrial cells to the surgical area during the operation ${ }^{(8,9)}$. All our study patients with endometriosis localized on the abdominal wall had EE after the cesarean section in accordance with this theory. In addition, fine needle biopsies applied for the abdominal wall endometriomas are known to pose a risk for the development of a new lesion ${ }^{(10)}$. Although needle biopsy might be useful in the diagnostic stage for extreme cases, pathological examination is crucial for making a definitive diagnosis. For this reason, we excised the endometriomas leaving safety margins for all patients. We used a prolene mesh to repair the post-excision defect in only one patient.

Therefore, in cases of EE disruption, endometrial tissues can be transplanted to the wound. However, it should not be forgotten that endometriosis can be detected on the abdominal wall after surgical procedures such as appendectomy and hernia, despite the absence of a previous obstetric or gynecological history ${ }^{(5)}$. In addition, some studies have reported that $25 \%$ of abdominal wall endometriosis coexist with concurrent pelvic endometriosis. Therefore, the patients must be evaluated in this context as well ${ }^{(11)}$.

In this study, mass and cyclic pain were identified as the most common clinical manifestations of EE. Based on the literature, the most frequently observed symptoms are presence of a mass and pain, although some patients may be asymptomatic ${ }^{(12)}$. This is why when a mass is detected in a patient who had undergone gynecological surgery, especially when the mass is close to the scar tissue, endometrioma should be considered in the differential diagnosis, regardless of whether the pain is associated with the mass.

The most common symptom among patients with abdominal wall endometriosis was found to be the mass, and the second most common symptom was cyclic pain. Based on the results of preoperative anamnesis, physical examination and ultrasound imaging, EE was diagnosed correctly in more than twothirds of our patients. Suture granulomas, abscesses, hernia, hematomas and desmoid tumours should be considered in the differential diagnosis, and additional imaging methods should be carried out in certain cases ${ }^{(2)}$. In addition, if the clinician does not suspect this rare condition in the differential diagnosis and does not warn the pathologist, making a histopathological diagnosis might be problematic. At least two of the endometrial stroma, endometrial-like glands and hemosiderin pigments must be looked for during the pathological examination ${ }^{(13)}$; however, if the pathologist is not informed about this differential diagnosis in the absence of endometrial glands, the endometrial stroma and macrophages could be underdiagnosed. 
It has been reported in the literature that not cleaning the surgical site with saline after the surgery and the use of sutures or sponges contaminated with endometrial cells lead to the development of endometriosis on the abdominal wall. Considering the increasing rates of cesarean sections, performing a careful operation and irrigating the surgical area with saline solution and changing used surgical gloves and all materials at the end of the surgery are highly recommended to prevent the incidence of endometriosis ${ }^{(9,14)}$.

This study has demonstrated that the excision of the mass with safety margins is sufficient for the curative treatment of EE. Only one of our patients had recurrence during the follow-up period of approximately 4 years. Recurrence rates in the literature have been reported to be between $3 \%$ and $16 \%{ }^{(5,7)}$. The recurrence rate observed in our study is consistent with the literature and emphasises, once again, the importance of en bloc resection with clear boundaries.

Umbilical endometriosis is generally seen as secondary to a surgical incision, but when it occurs spontaneously, it is known as primary endometriosis. History of gynecological procedures in our cases suggests that our cases are secondary endometriosis. Medical therapy is an option in cases of umbilical endometriosis, but rarely cures it ${ }^{(15)}$. That is why, a surgical procedure might be preferred as demonstrated in our study. The literature indicates only excision of the mass and preservation of the umbilicus as treatment options ${ }^{(16)}$. In addition, total excision of the mass with the umbilicus has been recommended to prevent recurrence, regardless of the size and location of endometriosis ${ }^{(17)}$. Given the increasing aesthetic concerns today, we consider protection of the umbilicus, especially in young patients, as a more appropriate and sufficient treatment option.

Female patients generally visit the general surgery outpatient clinics with a diagnosis of masses detected in the inguinal area. However, the literature states that this uncommon pathology is hardly recognised by general surgeons due to its rarity ${ }^{(18)}$. Therefore, if a woman with a gynaecological surgical history has a particularly painful mass in the inguinal area, the surgeon should suspect inguinal endometriosis that might provide a recurrent hernia appearance as a differential diagnosis ${ }^{(19)}$.

Our research naturally has the limitations of a retrospective study. In addition, subgroup analyses were not performed due to the low number of cases.

Extrapelvic endometrioma should be suspected in patients wo had gynecological surgery and mass in the abdominal wall in the differential diagnosis, regardless of the occurrence of cyclic pain. Regarding the treatment of extrapelvic endometrioma located in the wall of the abdomen, excision with safety margins is sufficient. The fact that the masses are far from the scar tissue should not be a criterion of exclusion this entity in the differential diagnoses, and surgeons need to be aware of this issue.

\section{REFERENCES}

1. Giudice LC, Kao LC. Endometriosis. Lancet. 2004;364(9447):1789-99. https://doi.org/10.1016/S0140-6736(04)17403-5

2. Chamié LP, Ribeiro DMFR, Tiferes DA, Macedo Neto AC de, Serafini PC. Atypical sites of deeply infiltrative endometriosis: clinical characteristics and imaging findings. Radiographics. 2018;38(1):309-28. https://doi.org/10.1148/rg.2018170093

3. Blanco RG, Parithivel VS, Shah AK, Gumbs MA, Schein M, Gerst PH. Abdominal wall endometriomas. Am J Surg. 2003;185(6):596-8. https://doi.org/10.1016/S0002-9610(03)00072-2

4. Douglas C, Rotimi O. Extragenital endometriosis--a clinicopathological review of a Glasgow hospital experience with case illustrations. J Obstet Gynaecol. 2004;24(7):804-8. https://doi.org/10.1080/01443610400009568

5. Alanbay İ, Çoksüer H, Ercan CM, Karaşahi n E, Keski ’n U, Güler AE, et al. Batın Ön Duvarı Skar Endometriozisi: 12 Olgu ve Literatür İncelemesi. JCOG. 2012;22(2):125-30.

6. Akdemir A, Akman L, Yavuzsen HT, Zekioglu O. Clinical features of patients with endometriosis on the cesarean scar. Kaohsiung J Med Sci. 2014;30(10):541-3. https://doi.org/10.1016/j.kjms.2013.12.001

7. Khamechian T, Alizargar J, Mazoochi T. 5-Year data analysis of patients following abdominal wall endometrioma surgery. BMC Womens Health. 2014;14:151. https://doi.org/10.1186/s12905-014-0151-4

8. Witz CA. Current concepts in the pathogenesis of endometriosis. Clin Obstet Gynecol. 1999;42(3):566. https://doi.org/10.1097/00003081-199909000-00013

9. Teng CC, Yang HM, Chen KF, Yang CJ, Chen LS, Kuo CL. Abdominal wall endometriosis: an overlooked but possibly preventable complication. Taiwan J Obstet Gynecol. 
2008;47(1):42-8. https://doi.org/10.1016/S1028-4559(08)60053-4

10. Matthes G,Zabel DD, Nastala CL, Shestak KC. Endometrioma of the abdominal wall following combined abdominoplasty and hysterectomy: case report and review of the literature. Ann Plast Surg. 1998;40(6):672-5. https://doi.org/10.1097/00000637-199806000-00019

11. Zhu Z, Al-Beiti MAM, Tang L, Liu X, Lu X. Clinical characteristic analysis of 32 patients with abdominal incision endometriosis. J Obstet Gynaecol. 2008;28(7):742-5. https://doi.org/10.1080/01443610802463744

12. Üstüner I, Üstüner E, Atman ED, Şentürk S, Balik G, Ural ÜM, et al. Batın ön duvarı skar endometriozisi: Olgu serisi ve görüntüleme yöntemlerinin incelenmesi. Turk J Obstet Gynecol. 2014;11(1):71-7. https://doi.org/10.5505/tjod.2014.65983

13. Dwivedi AJ, Agrawal SN, Silva YJ. Abdominal Wall Endometriomas. Dig Dis Sci. 2002;47(2):456-61. https://doi.org/10.1023/A:1013711314870

14. Kafadar MT, Miryaguboğlu AM, Yalaza M, Değirmencioğlu G, Şen M. Sezaryen sonrası saptanan kesi fitığını taklit eden rektus abdominis kası yerleşimli endometriozis. FNG \& Bilim Tıp Dergisi. 2017;3(1):38-41. https://doi.org/10.5606/fng.btd.2017.008

15. Victory R, Diamond MP, Johns DA. Villar's nodule: a case report and systematic literature review of endometriosis externa of the umbilicus. J Minim Invasive Gynecol. 2007;14(1):23-32. https://doi.org/10.1016/j.jmig.2006.07.014

16. Fancellu A, Pinna A, Manca A, Capobianco G, Porcu A. Primary umbilical endometriosis. Case report and discussion on management options. Int $\mathrm{J}$ Surg Case Rep. 2013;4(12):1145-8. https://doi.org/10.1016/j.ijscr.2013.11.001

17. Mechsner S, Bartley J, Infanger M, Loddenkemper C, Herbel $\mathrm{J}$, Ebert AD. Clinical management and immunohistochemical analysis of umbilical endometriosis. Arch Gynecol Obstet. 2009;280(2):235-42. https://doi.org/10.1007/s00404-008-0900-4

18. Nirula R, Greaney GC. Incisional endometriosis: an underappreciated diagnosis in general surgery. J Am Coll Surg. 2000;190(4):404-7. https://doi.org/10.1016/S1072-7515(99)00286-0

19. Boz A, Yildirim M, Erkan N, Selek E. Ekstragenital Endometriozis (Bir Olgu Sunumu). ADÜ Tıp fakültesi Dergisi. 2003;4(1):25-6. 